\title{
顎関節突起骨折に対する各種骨内固定法の生体力学的評価
}

\author{
三森康弘・冨永和宏・カナルアミット \\ 土生学・平島怱一・福田仁一
}

\section{A biomechanical evaluation of bone stability with different types of rigid internal fixation techniques for subcondylar fractures}

\author{
MIMORI Yasuhiro $\cdot$ TOMINAGA Kazuhiro $\cdot$ KHANAL Amit \\ HABU Manabu $\cdot$ HIRASHIMA Soichi $\cdot$ FUKUDA Jinichi
}

\begin{abstract}
The purpose of this study was to evaluate the biomechanical stability of various rigid internal fixation systems for subcondylar fractures.

Fifteen identical synthetic polyurethane mandibles with a cancellous bone structure (Synbone ${ }^{\circledR}$, Switzerland) were used. The left condylar processes were cut with a band saw to mimic subcondylar fractures directed perpendicularly to the long axis of the ramus, and the right sides were cut to mimic oblique fractures to the ramus. The fixation systems used were a single 4-hole titanium mini-adaptation plate (Synthes), double fixation with the same plates, a single 5-hole titanium mini-dynamic compression plate (Synthes), an Eckelt lag screw ${ }^{\circledR}$ system (Martin), and a Wurzburg lag screw plate ${ }^{\circledR}$ system (Leibinger). Biomechanical testing was done as described by Haug et al. (1996). The bone models were held with a custom-made jig to keep the occlusal plane horizontal. The canine region was pressed with a cantilever beam design using a servohydraulic testing machine (Autograph, Shimadzu) at a rate of $1 \mathrm{~mm} / \mathrm{sec}$. The force-displacement curve, maximum load for breakage, and stiffness were measured.

In perpendicular fractures, double mini-plate fixation and Eckelt lag screw fixation provided the best stability. The maximum loads of the former and the latter were $46.7 \pm 9.5 \mathrm{~N}$ and $44.7 \pm 11.6 \mathrm{~N}$, respectively. Their stiffness was $4.1 \pm 1.1 \mathrm{~N} / \mathrm{mm}$ and $4.7 \pm 1.9 \mathrm{~N} / \mathrm{mm}$, respectively. Single mini-plate fixation was weakest, i.e., $13.2 \pm$ $2.4 \mathrm{~N}$ maximum load and $1.3 \pm 1.0 \mathrm{~N} / \mathrm{mm}$ stiffness. In oblique fractures, double mini-plate fixation also had the best tolerance for load and stiffness, i.e., $55.1 \pm 11.6 \mathrm{~N}$ and $5.2 \pm 2.7 \mathrm{~N} / \mathrm{mm}$, respectively. The Eckelt lag screw, however, showed considerably less fixation strength than that for perpendicular fractures, i.e., $22.8 \pm 11.3 \mathrm{~N}$ for load tolerance and $1.0 \pm 0.2 \mathrm{~N} / \mathrm{mm}$ for stiffness.

In this laboratory setting, double mini-plate fixation proved superior in both types of fractures with regard to resistance to movement and breakage strength. The Eckelt lag screw showed good stability for perpendicular fractures; however, stability was weak for oblique fractures. Not only single mini-plate fixation but also minidynamic compression plate fixation or a Wurzburg lag screw plate system may provide insufficient fixation strength for this type of fracture on early functional loading.
\end{abstract}

Key words: subcondylar fracture（関節突起基底部骨折), biomechanical evaluation（生体力学的評価）, internal fixation method（骨内固定法）, mini-plate（ミニプレート), lag screw（ラグスクリュー）

緒

言

顎関節突起骨折の観血的治療の適応については古くから

九州㐘科大学口腔外科学第 1 講座

(主任：福田仁一教授)

First Department of Oral and Maxillofacial Surgery, Kyushu

Dental College (Chief: Prof. FUKUDA Jinichi)

受付日：2004 年 3 月 5 日

採択日：2004 年 6 月 29 日
議論されてきたが, 多くの臨床的研究 ${ }^{1 \sim 4)}$ により, 最近 では成人の関節突起頸部や基底部の骨折で，小骨片が大き く転位していたり，下顎窩から脱臼しているような症例は， 観血的治療の適応であろうという見解が広く支持されるよ うになってきた ${ }^{5 ， 6)}$. しかし，観血的に整復された骨片を 固定する方法に関しての統一した見解はなく，また，近年， 顎関節突起骨折のためのさまざまな骨内固定装置が開発さ れてきたこともあり，以前にも增してどのような固定法を 

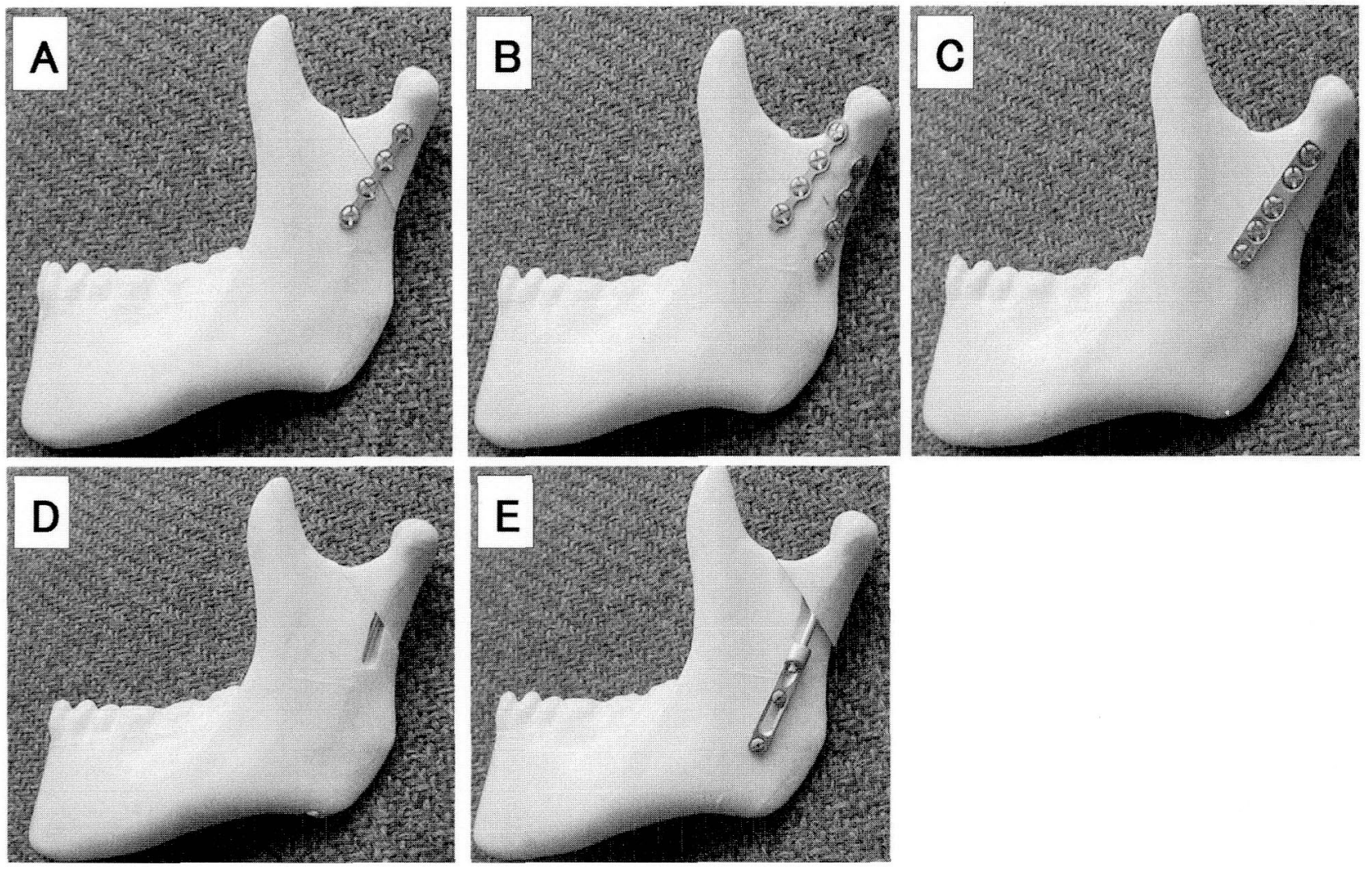

図 1 実験に用いた各種固定装置

A: single adaptation plate, B: double adaptation plate, C: zygomatic DC plate,

D: Eckelt lag screw, E: Wurzburg lag screw plate

選択すべきかの判断が難しくなっている。また，広く使用 されているチタン製の mini adaptation plate による固定を 行って，プレートの破折やスクリューの緩みを経験すること があるのも事実で, そのような報告も多数なされている7,8).

今回，わ机われは，この部の骨折の適切な固定方法につ いて明らかにするために，現時点で顎関節突起骨折に対し て使用可能なさまざまな骨内固定装置を下筫骨モデルに用 いて, 生体力学的に評価した.

\section{材料ならびに方法}

実験には海綿骨様構造を備えたポリウレタン製の下顎骨 モデルであるSynbone ${ }^{\circledR}$ (Synbone 社㡀) を用いた。左の 関節突起には骨モデルを後方から見て下顎枝の長軸に対し て垂直方向に骨折した横骨折モデルを，右の関節突起には 臨床的に遭遇することが比較的多い下䪽枝に対して斜めに 骨折した斜骨折モデルを作製した。斜骨折は下頑枝を後方 から見て $45^{\circ}$ 下外側に傾斜した骨折とした。骨モデルの 関節突起基底部をダイヤモンドソートリマー（MC-130D, Maruto 社製）にて規格化されたステントを用いて切断し た.
固定には 1）4穴のチタン製 mini adaptation plate ; マン ディブルミニプレート $2.0^{\circledR}$ (Synthes 社製，厚さ $1.0 \mathrm{~mm}$ ) 1 枚を $2.0 \mathrm{~mm}$ セルフタッピングスクリュー ${ }^{\circledR}$ (Synthes 社 製，長さ $6 \mathrm{~mm}$ ）で固定する方法と，2）同プレートを 2 枚 使用する方法，3）5穴の mini dynamic compression plate (以下, DCP) ; ジゴマティック DCP プレート $2.0{ }^{\circledR}$ (Synthes 社製，厚さ $0.8 \mathrm{~mm}$ ) 1 枚を $2.0 \mathrm{~mm}$ セルフタッピ ングスクリュー ${ }^{\circledR}$ で固定する方法，4）Eckelt lag screw ${ }^{\circledR}$ （Martin 社製，直径 $2.0 \mathrm{~mm}$ ，長さ $60 \mathrm{~mm}$ ）による固定，なら びに5) Wurzburg lag screw plate ${ }^{\circledR}$ (Leibinger 社製, collum screw；直径 $2.0 \mathrm{~mm}$ ，長さ $21 \mathrm{~mm}$ 使用）による固定の 5 種類を用いた（図 1)。横骨折，斜骨折のそれぞれに対し， 各固定法を 3 例ずつ行った。 な招，必要最低限の屈曲で最 適なプレート屈曲ができるようにプレートはモデルを切断 する前に予め屈曲適合させたものを使用した。

強度の測定には自動制御式水圧圧縮・曲げ試験装置 Autograph（AGS-5k NG，Shimadzu 社製）を用いた。荷重 のかけ方はHaug ら ${ }^{9)}$ が下顎角部骨折に対するプレート 固定法の生体力学的評価に際して用いた方法に従い, 咬合 平面を床面と平行にした状態で，頭関節部を特製のジグに 固定し，犬荿部にプッシュロッドを当て，片持ち梁式に下 
表 1 横骨折時の最大荷重とスティッフネス

\begin{tabular}{lcccr}
\hline \multicolumn{1}{c}{ fixation system } & maximum load & $\begin{array}{c}\text { calibrated load in the } \\
\text { condyle }\end{array}$ & stiffness & $\begin{array}{c}\text { calibrated stiffness } \\
\text { in the condyle } * *\end{array}$ \\
\hline single adaptation plate & $13.2 \pm 2.4$ & $63.4 \pm 11.6$ & $1.3 \pm 1.0$ & $29.8 \pm 22.0$ \\
double adaptation plate & $46.7 \pm 9.5$ & $224.0 \pm 45.5$ & $4.1 \pm 1.1$ & $94.5 \pm 25.3$ \\
zygomatic DC plate & $24.2 \pm 8.9$ & $116.3 \pm 42.7$ & $1.7 \pm 0.2$ & $39.0 \pm 5.2$ \\
Eckelt lag screw & $44.7 \pm 11.6$ & $214.3 \pm 55.9$ & $4.7 \pm 1.9$ & $109.0 \pm 43.4$ \\
Wurzburg lag screw plate & $18.1 \pm 6.4$ & $87.0 \pm 30.8$ & $1.2 \pm 0.2$ & $27.7 \pm 3.5$ \\
\hline
\end{tabular}

* : For the calibration 4.8 is multiplied (see Fig. 6). **: For the calibration $4.8^{2}$ is multiplied (see Fig. 6).

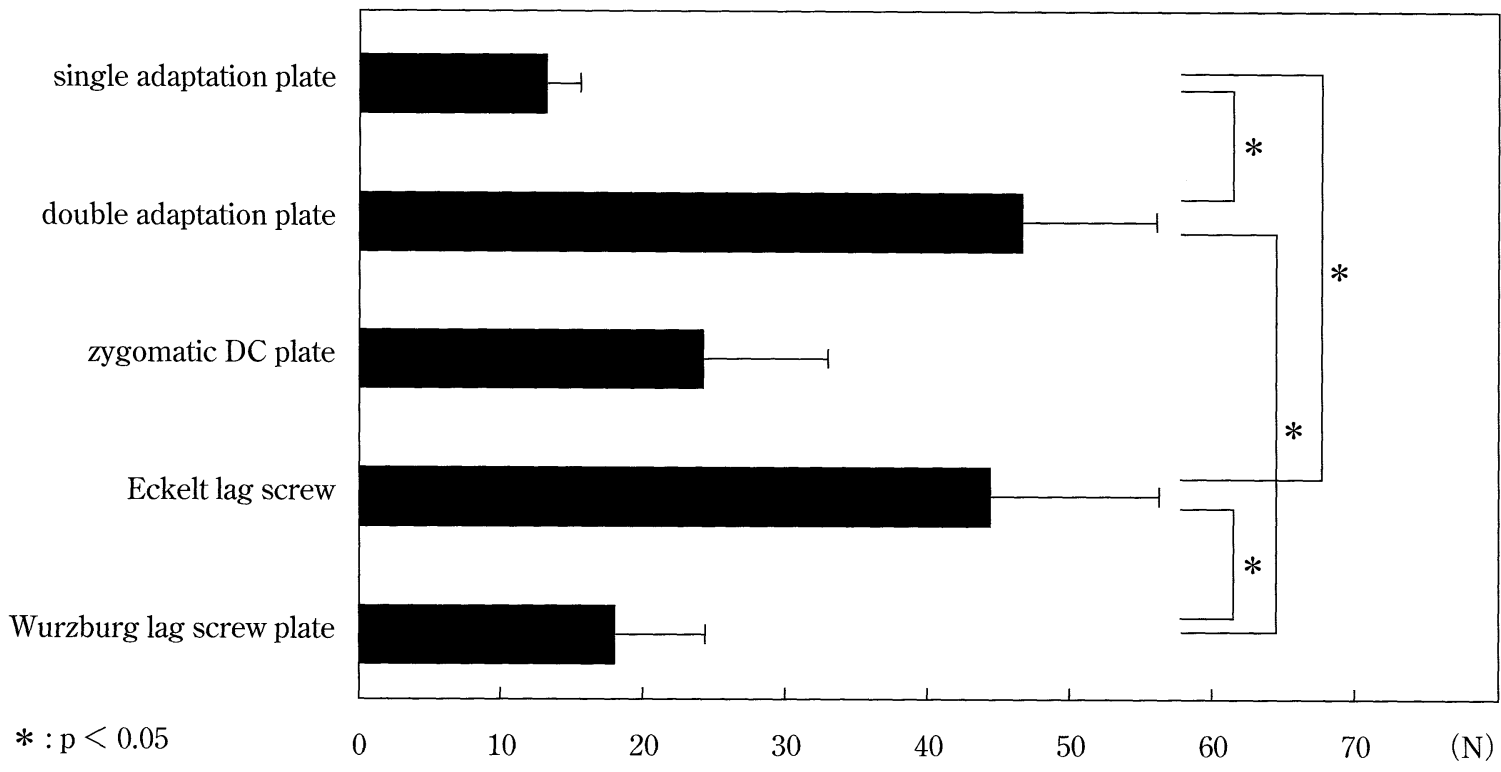

図 2 横骨折時の各種固定装置の最大荷重

方に向かって $1.0 \mathrm{~mm} / \mathrm{sec} の$ 割合で荷重をかけていき，その 際の荷重一変位曲線を記録した。この方法で下方に圧迫 していくと骨体部が外側に偏位していく傾向にあったた め，今回は押し始めから $20 \mathrm{~mm}$ 下方に変位した時点までの 荷重一変位曲線から最大荷重点とスティッフネス（剛性） を算出した。最大荷重点は材料が永久変形を起こす荷重で あり, 荷重 一 変位曲線の頂点にあたる部分の荷重値とし た. スティッフネスは材料の堅さを示す指標で, 荷重一変 位曲線の傾きの中で最も高い值を採用した。

横骨折群，斜骨折群内における違いは一元配置分散分析 を，おのおのの固定法間の違いは $t$ 検定を用い，有意水準 $5 \%$ 以下を有意差ありと判定した.

\section{結果}

横骨折群の結果をみると, 比較的良好な強度を示したの は mini adaptation plate 2 枚による固定と Eckelt lag screw 固定で，最大荷重はそれぞれ $46.7 \pm 9.5 \mathrm{~N} ， 44.7 \pm 11.6 \mathrm{~N}$ で
あり，スティッフネスはそれぞれ $4.1 \pm 1.1 \mathrm{~N} / \mathrm{mm}, 4.7 \pm$ $1.9 \mathrm{~N} / \mathrm{mm}$ であった（表 1 ，図 2，3）。最も強度が低かった のは mini adaptation plate 1 枚による固定で，最大荷重 $13.2 \pm 2.4 \mathrm{~N} ，$ スティッフネス $1.3 \pm 1.0 \mathrm{~N} / \mathrm{mm}$ であった。 DCP, Wurzburg lag screw plate はその中間であった.

斜骨折群においても mini adaptation plate 2 枚による固 定が最も高い強度を示し，最大荷重 $55.1 \pm 11.6 \mathrm{~N} ，$ スティ ッフネス $5.2 \pm 2.7 \mathrm{~N} / \mathrm{mm}$ であった（表 2 , 図 4, 5). 一方， 横骨折で良好な固定力を示していた Eckelt lag screw は著 しく強度を落とし，DCP とほぼ同程度の最大荷重ならびに スティッフネスしか示さなかった. なお，Wurzburg lag screw plate は下顎枝の外側から $10^{\circ}$ にオフセッされた collum screw で下外方にラグスクリュー効果を発揮させる ものであるが，今回の設定のような斜骨折においては骨片 のすべりを生じ，固定力を発揮できず，結果に大きなばら つきが出たため, 斜骨折における Wurzburg lag screw plate の評価は行えなかった. 


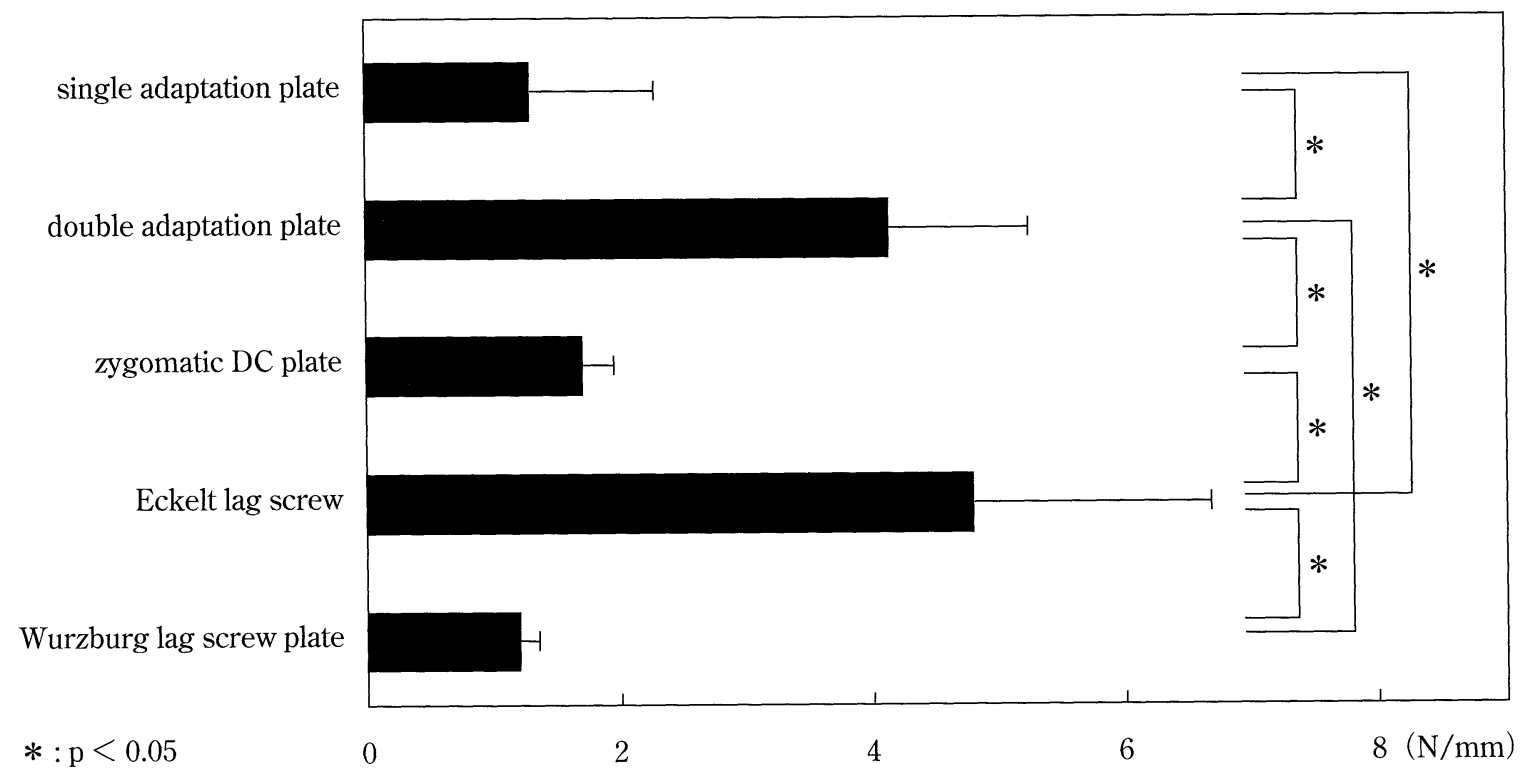

図 3 横骨折時の各種固定装置のスティッフネス

表 2 斜骨折時の最大荷重とスティッフネス

\begin{tabular}{lccrc}
\hline \multicolumn{1}{c}{ fixation system } & maximum load & $\begin{array}{c}\text { calibrated load in the } \\
\text { condyle }\end{array}$ & stiffness & $\begin{array}{c}\text { calibrated stiffness } \\
\text { in the condyle }\end{array}$ \\
\hline single adaptation plate & $9.4 \pm 1.8$ & $45.2 \pm 8.8$ & $0.8 \pm 0.5$ & $18.1 \pm 10.8$ \\
double adaptation plate & $55.1 \pm 11.6$ & $264.7 \pm 55.8$ & $5.2 \pm 2.7$ & $120.0 \pm 61.4$ \\
zygomatic DC plate & $20.0 \pm 10.2$ & $96.0 \pm 49.1$ & $0.9 \pm 0.1$ & $21.5 \pm 1.6$ \\
Eckelt lag screw & $22.8 \pm 11.3$ & $109.3 \pm 54.4$ & $1.0 \pm 0.2$ & $22.4 \pm 4.9$ \\
Wurzburg lag screw plate & $\mathrm{NA}^{* * *}$ & & NA*** $^{* *}$ & \\
\hline
\end{tabular}

$*$ : For the calibration 4.8 is multiplied (see Fig. 6). ** : For the calibration $4.8^{2}$ is multiplied (see Fig. 6).

$* * *$ : Not appreciable (see text)

考察

顎関節突起骨折に対する固定装置の in vitroに打ける強 度評価を行った研究は比較的少ない.われわれと類似の合 成樹脂製の下顎骨を用いた Ziccardi ら ${ }^{10 ） は W u r z b u r g ~ l a g ~}$ screw plate と mini adaptation plate を比較しており, Haug ら 11) は 4 種類のプレートの強度をわれわれと同じ Synbone ${ }^{\circledR}$ を用いて比較している。また, Choi ら ${ }^{12)}$ はヒ トの下顎骨を用い，3種類のプレートと mini adaptation plate 2 枚による固定との比較をしている．われわれが用い た下顎骨モデルである Synbone ${ }^{\circledR}$ は実際のヒト下顎骨の 印象を採得し，それを基に規格化して作製されたもので， 形状はヒトの骨そのものである。また，本モデルは周囲の 皮質骨様部と内部の海綿骨様部からなっており, 性状も七 トの骨と類似であることが確認されている ${ }^{13)}$ 。このように 形態，性状ともにヒト顎骨と類似の規格化されたモデルの 使用は，このような実験系には最も適したもので，年齢，
性別，生前の顎骨の状態などがさまざまで，大きさも画一 化できないヒトの骨で行う実験より再現性が高いと考えら れる。

Ziccardi ら ${ }^{10)}$ は咬合力を想定し, 骨体部を固定した状態 で顎関節部に荷重を加え, その際の組織内固定装置の強度

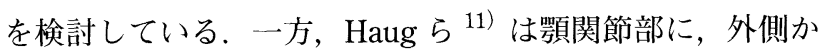
ら内側, 内側から外側, さらに後方から前方といった荷重 を加え，その際の固定装置の許容荷重とスティッフネスを 測定した。これは顎関節にはさまざまな方向からの荷重が 加わるため, Ziccardi ら ${ }^{10)}$ が行ったような一方向からだけ の荷重では不十分であるとの考えから行われたものである が，ヒトの下顎骨と同様の形態をもつ骨モデルを用いる実 験の利点は, 咀嚼や咬合などで骨の各部に生じる応力をモ デル上でシミュレートできることであり，単なる内方から 外方，外方から内方といった荷重のかけ方ならば，板状の

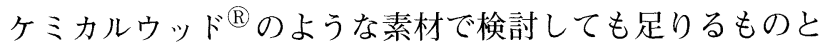
考えられる. したがって，われわれはZZiccardi ら ${ }^{10)}$ と同様 


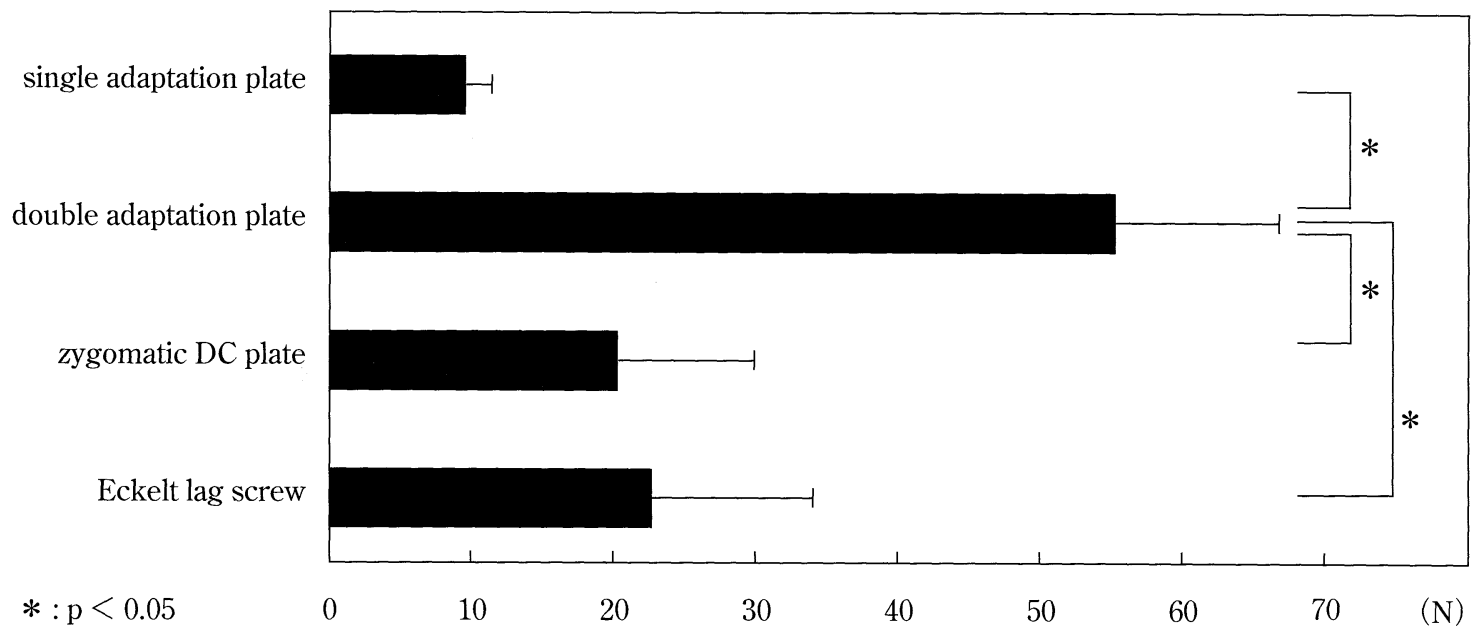

図 4 斜骨折時の各種固定装置の最大荷重

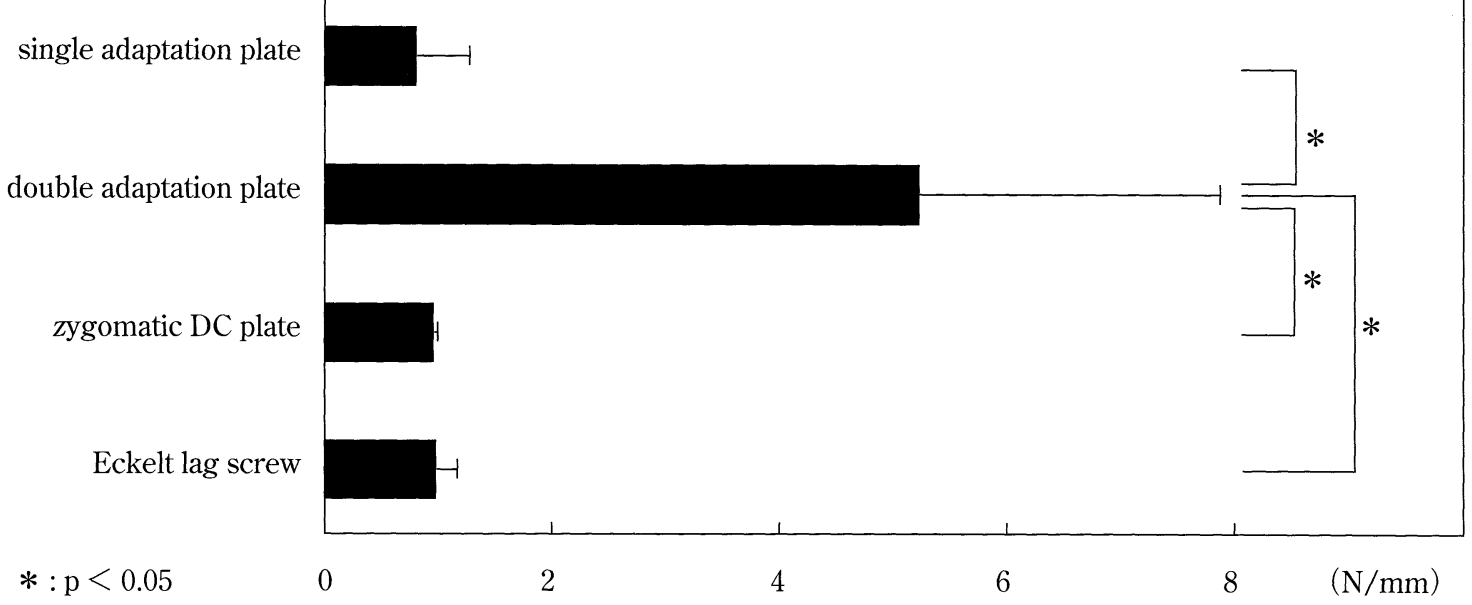

図 5 斜骨折時の各種固定装置のスティッフネス

のコンセプトで, 咬合力による応力を三次元数学モデルで 解析した Koolstra ら ${ }^{14 ）}$ の報告に従い，咬合力を想定した 荷重を一方向から加え, 関節突起部に生じる応力に対する 固定装置の強度を観察した。なお，われわれが用いた荷重 の加え方は下顎角骨折の固定装置の強度を検討する際に用 いられることが多い方法であるが，関節突起部に荷重を加 えていたZiccardi ら ${ }^{10 ）}$ の方法と基本的に差異はなく，後 述の方法により龥関節部に加わる荷重に換算できると考え ている.

Talwar $5^{15 ）}$ は両側の顎関節突起骨折患者の治療後の咬 合力の変化を検討している．それによると対照として検討 された健常者の咬合力が右の盽蒾部で $430.2 \pm 126.4 \mathrm{~N}$ ，左 の曰菊部で $440.2 \pm 155.8 \mathrm{~N}$ であったのに対し，患者群では 治療後 6 週の時点で，右が $161.7 \pm 84.3 \mathrm{~N}$ ，左が $169.5 \pm$ $75.7 \mathrm{~N}$ であったとされる。顎骨に加わる力を数学モデルで
解析した Koolstra ら ${ }^{14)}$ によると， 田菊部でのかみしめ時 に生じる顎関節部の応力はかみしめ力の $65 \%$ にぶとさ れている。皇れらを考慮すると健常者の顎関節には $300 \mathrm{~N}$ 程度の荷重が加わる可能性があり, 両側性の顎関節突起骨 折の患者の場合, 術後 6 週以内ではおよそ $100 \mathrm{~N}$ の力が及 ぶことが考えられる。

Throckmorton と Dechow ${ }^{16)}$ は in vitroの系でヒトの下 顎骨を用いて咬合力に相当する荷重を加えた場合，関節突 起の前方と外側に牽引力がかかり，下顎枝の後面に圧縮力 がかかることを明らかにしている，今回の実験でも荷重を 加えていくにしたがい，骨折線の下顎枝後縁部を中心に骨 体部が下方に回転していき，関節突起の前縁が開大してい く所見が認められた。このため，われわれやZiccardi ら 10) の力学系は図 6 に示すような比較的単純な軸運動として捉 えることもできると考えられる。これを基にして今回の実 


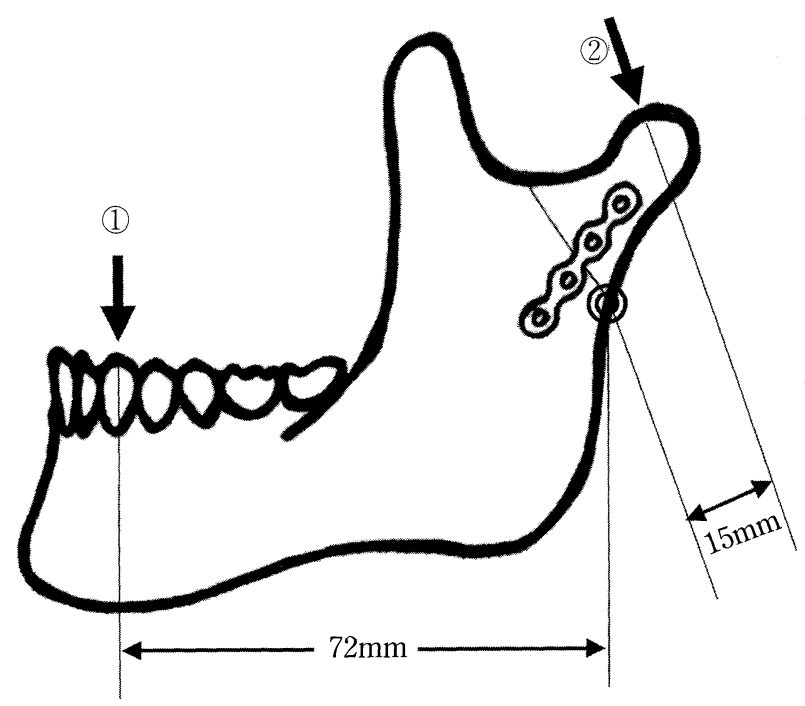

図 6 われわれの荷重方法(1)とZiccardi $5^{10)}$ の荷重方 法(2)

荷重初期には○部を中心として軸運動するため, (1)に おける荷重は $72 / 15$ ，すなわち 4.8 を乗ずることで(2)部に 加わると予想される荷重に換算できる，同様にスティッ フネスの換算には $4.8^{2}$ を乗ずる.

験による最大荷重を顎関節部に加わる荷重に換算し直して みると, mini adaptation plate 1 枚固定の平均值は $63.4 \mathrm{~N}, 2$ 枚固定は $224.2 \mathrm{~N}$, DCP は $116.2 \mathrm{~N}$, Eckelt lag screw は 214.6N, Wurzburg lag screw plate は 86.9N ということにな る(表 1).

以上のような点を考慮して, 今回の横骨折群の結果をみ ていくと, 顎関節部の荷重として換算し直された最大荷重 が $100 \mathrm{~N}$ を超えていたのは，mini adaptation plate 2 枚によ る固定と Eckelt lag screw，ならびに DCP による固定で, mini adaptation plate 1 枚による固定と Wurzburg lag screw plate は十分な固定力をもっているとはいえないようであ った. Ziccardi ら ${ }^{10)}$ の実験では mini adaptation plate と Wurzburg lag screw plate の許容荷重はそれぞれ $39.2 \mathrm{~N}$, $49.0 \mathrm{~N}$ であった。彼らが使用した下顎骨モデルの形状はわ れわれが使用したモデルとは異なるため, 完全な一致は当 然望めないが, Wurzburg lag screw plate が mini adaptation plate 1 枚に比べてやや強いものの, どちらも十分な強度を もっていないという点で一致していた.

DCPに関しては，われわれの結果を買関節部の荷重に換 算すると平均值がぎりきり $100 \mathrm{~N}$ を超えてはいるが, 術後 早期に顎関節を機能させるにはやはり十分な強度をもつと はいえないと考える. Haug ら ${ }^{11)}$ は mini adaptation plate や zygomatic DCP の他に $1.0 \mathrm{~mm}$ 厚の mini dynamic compression plate; DCP プレートミニ $2.0{ }^{\circledR}$ (Synthes 社製) と Compact lock 2.0 システム ${ }^{\circledR}$ (Synthes 社製) を Synbone ${ }^{\circledR}$ に適応し，in vitroの実験を行っている. その結果として， これらのプレート類の中では $1.0 \mathrm{~mm}$ 厚の DCP が比較的高 い強度を示したが，1枚のプレート固定ではいずれのプレ 一トも臨床的に必要な強度は満たしていない可能性がある と述べている。

Choi ら ${ }^{12)}$ はヒトの下顎骨を用いて関節突起骨折モデル を作製し, mini adaptation plate, DCP, $2.4 \mathrm{~mm}$ プレート各 1 枚固定と 2 枚の mini adaptation plate 固定の生体力学的評 価を行い, 2 枚の mini adaptation plate 固定がこの部の固定 に最も適していると記している. 合成樹脂モデルとヒトの 顎骨という素材の違いだけでなく，実験方法も異なるので， 彼らのデータとの直接的比較は困難であるが，注目すべき ことは彼らの結果では, mini adaptation plate 1 枚に対して, 2 枚使用した場合は 4 倍強の強度に達していたことである. われわれの結果でも最大荷重が 3 倍以上になっており，ス ティッフネスも 3 倍以上に増加していた。 これは先述した ように咬合時には関節突起の前方に率引力が加わり, 後方 では圧縮力が加わることから考えると，それに抗するよう に配置されたプレートが強度を大幅に増加させた結果であ ろうと推測された.

Eckelt lag screw について，このような in vitroの系で検 討を加えた報告は渉猟した限りみられない. Sugiura ら 17$)$ は Eckelt lag screw で固定された症例と mini adaptation plate 固定ならびにキルシュナー鋼線固定の症例の術後 6 か月とさらに長期 (7 から 106 か月後; 平均 18.4 か月後) の臨床的ならびにX 線学的評価を行い, Eckelt lag screw 固定を行った症例が最も良好な結果を示したことを報告し ている。今回の結果でも横骨折時の Eckelt lag screw は mini adaptation plate 2 枚による固定と同等かそれ以上の最 大荷重とスティッフネスを備えていることが明らかにな り, 彼らの臨床的結果を裏付けるものとなった.

顎関節突起骨折において下顎枝の長軸に対して斜めに骨 折線が入る，いわゆる斜骨折はしばしば臨床で遭遇する ${ }^{7}$. しかし，そのような骨折に対して行った骨内固定法の生体 力学的強度を検討した報告は過去にはなされておらず，他 との比較検討はできないが，今回の結果には大変興味深い ものが含まれていると考えている．すなわち，プレート類 は斜骨折時も横骨折時とほほ同様の結果であったのに対 し, Eckelt lag screw による固定は最大荷重が横骨折時の半 分となり, スティッフネスは 4 分の 1 以下となっていたこ とである. Spiess1 ${ }^{18)}$ は斜骨折に対して骨の長軸方向に压 迫骨接合の力を働かせると骨折面で剪断力が生じ，これが 骨片間の圧迫を失わせるだけでなく，断層作用を起こすと 述べている. また， $45^{\circ}$ の斜骨折では長軸方向の圧迫力の $30 \%$ 剪断力に変換されるとも述べており, Eckelt lag screw の固定力の低下はこのような現象により生じたもの 
と考えられた．実際の臨床で遭遇する斜骨折は全体として は斜めに折れているものの，今回の設定のような平滑な断 面形状ではなく，骨折断端は鋸菌状を呈して扔り，骨片の 整復後には interdigitation 効果が期待できるため，実際に はこれほど著しい固定力の低下が起こるとは考えられな い.しかし，今回の結果はこのような骨折に対する lag screw 法の適用に注意を促す結果ではあると考えている.

以上の結果を総合的に判断すると，関節突起基底部骨折 に対する骨内固定法として，どのような骨折様態において も早期の機能負荷に十分耐えられる強度が得られる固定法 は, 2 枚の mini adaptation plateによる固定であると考えら れた。なお，このような固定法を確実に行うためには，下 顎枝部の広い術野の展開が必要となるが，われわれは下顎 枝後方アプローチ19）を用いることで，mini adaptation plate 2 枚による固定を行っており，このアプローチ法がこ の固定法には最も適すると考えている.

\section{結語}

顎関節突起基底部骨折に対する骨内固定法の生体力学的 評価を行い, 以下の結果を得た。

1. 後方から見て下顎枝に対して垂直な骨折（横骨折） の場合，チタン製 mini adaptation plate 2 枚による固定と Eckelt lag screwによる固定が良好な結果を示した。

2. 後方から見て下顎枝に対して斜めに骨折している場 合（斜骨折）にも2 枚の mini adaptation plateによる固定 は十分な強度を示したが, Eckelt lag screw による固定強度 は横骨折時に比べて大きく低下していた。

3. 1 枚だけの mini adaptation plate や DCPによる固定, もしくは Wurzburg lag screw plateによる固定は, 術後早 期の機能負荷がかかる状況においては固定強度が不十分で ある可能性が窥われた。

稿を終えるにあたり，今回の実験において多大なるご協力 をいただきましたグンゼ株式会社研究開発部メディカル材料 センターの皆様に深謝いたします。

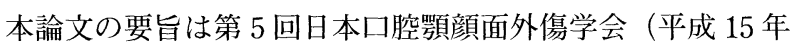
6 月, 徳島市) にて発表した.

\section{引用文 献}

1) Hayward, J.R. and Scott, R.F.: Fractures of the mandibular condyle. J Oral Maxillofac Surg 51: 57-61 1993.

2）冨永和宏，喜久田利弘，他：㖽関節突起骨折に対す る観血的療法の治療成績. 日口外誌 33: 2230-2238 1987.

3) Kikuta, T., Yasumitsu, C., et al.: Surgical treatment for condylar fractures of the mandible-Questionnaire study-. Asian J Oral Maxillofac Surg 3: 137-144 1991.

4) Hyde, N., Manisali, M., et al:: The role of open reduction and internal fixation in unilateral fractures of the mandibular condyle: a prospective study. Br J Oral Maxillofac Surg 40: 19-22 2002.

5) Baker, A.W., McMahon, J., et al.: Current consensus on the management of fractures of the mandibular condyle. Int J Oral Maxillofac Surg 27: 258-266 1998.

6) Bos, R.R.M., Booth, R.P.W., et al.: Mandibular condyle fractures: a consensus. Br J Oral Maxillofac Surg 37: 87-89 1999 .

7) Ellis, E. and Dean, J.: Rigid fixation of mandibular condyle fractures. Oral Surg Oral Med Oral Pathol Oral Radiol 76: 6-15 1993.

8) Hammer, B., Schier, J., et al.: Osteosynthesis of condylar neck fractures: a review of 30 patients. $\mathrm{Br} \mathrm{J}$ Oral Maxillofac Surg 35: 288-291 1997.

9) Haug, R.H., Barber, J.E., et al.: A comparison of mandibular angle fracture plating techniques. Oral Surg Oral Med Oral Pathol Oral Radiol Endod 82: 257-263 1996.

10) Ziccardi, V.B., Schneider, R.E., et al.: Wurzburg lag screw plate versus four-hole miniplate for the treatment of condylar process fractures. J Oral Maxillofac Surg 55: 602-607 1997.

11) Haug, R.H., Peterson, G.P., et al.: A biomechanical evaluation of mandibular condyle fracture plating techniques. J Oral Maxillofac Surg 60: 73-80 2002.

12) Choi, B.H., Kim, K.N., et al.: Evaluation of condylar neck fracture plating techniques. J Craniomaxillofac Surg 27: 109-112 1999.

13) Bredbenner, T.L. and Haug, R.H.: Substitutes for human cadaveric bone in maxillofacial rigid fixation research. Oral Surg Oral Med Oral Pathol Oral Radiol Endod 90: 574-580 2000.

14) Koolstra, J., van Eijden, J., et al.: A three dimensional mathematical model of the human masticatory system predicting maximum possible bite forces. J Biomech 21: 563-576 1988.

15) Talwar, R.M., Ellis, E., et al.: Adaptations of the masticatory system after bilateral fractures of the mandibular condylar process. J Oral Maxillofac Surg 56: 4304391998.

16) Throckmorton, G.S. and Dechow, P.C.: In vitro strain measurements in the condylar process of the human mandible. Archs Oral Biol 39: 853-867 1994.

17) Sugiura, T., Yamamoto, K., et al.: A comparative evaluation of osteosynthesis with lag screws, miniplates, or Kirschner wires for mandibular condylar process fractures. J Oral Maxillofac Surg 59: 1161-1168 2001.

18) Spiessl, B.: Osteosynthese des Unterkiefers. 1st Ed, Springer-Verlag, Berlin, 1988, p45-51.

19）福田雅幸, 高橋 哲, 他：下䫟枝後方切開による下 靧骨関節突起骨折の治療経験。 日外誌 46: 69-74 2000 . 